\title{
Alexander Schmemann. Za življenje sveta: zakramenti in pravoslavje.
}

\author{
Prev. Tina Osterman, spremna beseda David \\ Bresciani. Ljubljana: Družina, Založba Dravlje, \\ 2018. 159 str. ISBN: 978-961-04-0510-8.
}

Monografija Za življenje sveta: zakramenti in pravoslavje (For the Life of the World: Sacraments and Orthodoxy, 1963, druga izdaja 1973) pravoslavnega rusko-ameriškega akademskega teologa in duhovnika Alexandra Schmemanna (1921-1983) spada v zakladnico tistih še danes temeljnih del, nastalih sredi 20. stoletja, ki so odločilno pripomogla k poglobljenemu in sistematičnemu spoznavanju duhovnosti in zgodovine Pravoslavne cerkve med bralci v zahodnem svetu. Posebnost in dragocenost omenjenega Schmemannovega dela je dvojna: po eni strani je zasnovano v skladu z doktrinarno jasnim in do (post)modernega družbenega stanja odklonilnim izhodiščem pravoslavnega duhovnika, potomca ruskih političnih emigrantov, ki je spadal v krog zagovornikov t. i. neopatristične sinteze, to je prevladujoče "ustvarjalno tradicionalne« smeri v pravoslavni teologiji 20. stoletja, katere utemeljitelj je ruski teolog in zgodovinar Georgij Florovski (1893-1979); po drugi strani pa je napisano v razlagalno nazornem jeziku z obilico retoričnih prispodob, ki avtorjevo znanstveno podkovanost in kritičnost posreduje na živahen in osebno zavzet ter tako širšemu bralstvu dostopen način. Brez pretiravanja je mogoče trditi, da prav Schmemannova življenjska pot kot celota odraža njegovo željo po posredovanju »starodavne, a vselej sveže« dediščine pravoslavnega krščanstva zahodnemu človeku, ki je od nekdanje ukoreninjenosti v katoliško ali protestantsko različico iskanja življenjskega smisla prešel k sekularnim postulatom 
vrednostno relativistične in materialistično naravnane vsakdanjosti. Najustvarjalnejša in mednarodno najbolj prepoznavna leta je namreč kot profesor liturgične zgodovine in teologije preživel v Združenih državah Amerike, kjer je med drugim razmeroma dolgo (1962-1983) opravljal službo dekana Pravoslavnega teološkega semenišča sv. Vladimirja (Saint Vladimir's Orthodox Theological Seminary) v Crestwoodu pri New Yorku, ki je v njegovem času postal in do današnjih dni ostal osrednja pravoslavna teološka fakulteta na Zahodu. V številnih objavljenih delih in javnih nastopih, zlasti v odmevnih duhovnih nagovorih na znamenitem Radiu svoboda (Radio Liberty), je vztrajno poudarjal, da predstavlja liturgično izročilo Cerkve ključno sestavino in živ izraz krščanske vere, ki kaže na vstopanje večnosti v časnost, $s$ tem pa tudi na občestvo med zemeljsko Cerkvijo in svetniki v nebesih. S svojim znanstvenim ugledom in organizacijskimi sposobnostmi se je v novejšo zgodovino krščanstva zapisal tudi kot eden od utemeljiteljev avtokefalne Ameriške pravoslavne cerkve (Orthodox Church of America), katere jedro sestavljajo potomci ruskih priseljencev in spreobrnjenci $\mathrm{v}$ pravoslavje $\mathrm{z}$ raznolikim narodnostnokulturnim ozadjem. Dejavno je sooblikoval številne ekumenske dogodke in pobude, bil je tudi udeleženec drugega vatikanskega koncila (1962-1965), in sicer kot eden od pravoslavnih opazovalcev.

Rdečo nit Schmemannove monografije tvori razmerje med zakramenti in življenjem. Avtor poudarja misel, da človek hrepeni po življenju in zavrača to, kar ga spominja na smrt, pri čemer pa se ne zaveda, da vse, kar je minljivo, četudi se mu na prvi pogled zdi trdno in plemenito, življenja ne more zagotavljati. Na tej podlagi avtor zagovarja razsežnost zakramentalnega življenja, ki jo v skladu s tradicionalnim krščanskim naukom in prakso razume kot dejavno in preobražajočo božjo prisotnost skozi snovne podobe v minljivem svetu, ki ga posveča in zaobjema kot simbol in priložnost za odrešenje, usmerjeno k neminljivosti oz. večnemu življenju. Od tod zakramenti človeka učijo, naj celotno življenje in svet dojema kot božji dar, naj kljub vsem preizkušnjam živi v hvaležnosti Bogu, ki ga je ustvaril in odrešil ter ga po svoji navzočnosti v zakramentih vabi k »večni gostiji« ob izteku časov. Zakramenti človeka z Bogom in drugimi ljudmi, ki sestavljajo Cerkev kot skrivnostno Kristusovo telo, združujejo "tukaj in sedaj«, vendar ga obenem vodijo k cilju, to je svetosti, ki odpira vrata pridruženosti večnemu »božjemu kraljestvu«, katerega predpodoba je že vsebovana v zakramentih, zlasti evharistični daritvi. Po Schmemannu 
zakramentov ni mogoče ustrezno razumeti in doživljati zunaj Cerkve oz. njihove umeščenosti v bogoslužje in liturgično obhajanje praznikov. Zanj je namreč bistven pojem liturgične teologije, saj gre pri tem za takšno razumevanje in doživljanje, ki izhaja iz molitvene drže celotne Cerkve, to je iz najbolj osebnega (a ne zasebnega) in najbolj neposrednega odnosa z Bogom, ki združuje preteklost, sedanjost in prihodnost vseh v Kristusa včlenjenih generacij. Avtor se zaveda, da je za sekularizirano miselnost govorjenje o svetu kot zakramentu brezpredmetno. Za vernega človeka pa je tak pogled nepogrešljiv: kruh in vino kot simbol ustvarjenega sveta in človekovega dela oz. sodelovanja s Stvarnikom, ki se prinaša na oltar, sama po sebi še nista zakrament, vendar se na oltar prinašata prav zato, da to postaneta. Bolj ko človek v zaupljivi molitveni drži v božje roke izroča svet in zgodovino, v kateri živi, bolj vse to postaja zakrament. Brez zakramentalnega razumevanja sveta in življenja je vernik obsojen na razdvojenost med pričakovanjem posvetnega samouresničevanja in zahtevnimi krščanskimi ideali krepostnega življenja za prihod v »božje kraljestvo«; to vodi k ločevanju na posvetno življenje $\mathrm{v}$ javnosti in versko življenje $\mathrm{v}$ zasebnosti posameznika ali njegove družine, kar Schmemann ocenjuje kot nekaj nenaravnega in nesprejemljivega. Zato redno in zavestno zajemanje pri zakramentih kot »izvirih žive vode« ponuja nov pogled na resničnost zemeljskega življenja, ki ga zaznamujejo celovitost razuma in izkušnje, posameznika in skupnosti, časnosti in večnosti, sveta in Boga. Tak pogled ni človeško idealen, saj prihaja kot dar od Boga in je zato pogled upanja, ki ga človek sprejema v hvaležnosti. Na podlagi večstoletnega izročila Pravoslavne cerkve avtor predlaga, da je najučinkovitejša pot za življenje iz zakramentov vztrajno življenje ob tistih ljudeh, ki zakramentalno že poskušajo živeti ali so iz njih v svojem času živeli in s tem postali svetniki. Zakramentalno življenje tako predpostavlja občestvo z zemeljsko in nebeško Cerkvijo, s čimer je organsko povezana zvestoba (liturgičnemu) izročilu in njegovo ustvarjalno uresničevanje v vsakokratnem zgodovinskem trenutku.

S prevodom Schmemannove monografije, ki jo med drugim odlikuje prevajalkina sposobnost, da je živahnost avtorjevega sloga in pravoslavno (liturgično) terminologijo uspešno prestavila v drug jezik, slovenski kulturni prostor dobiva pomembno delo. Vedoželjnemu bralcu ne omogoča le globljega razumevanja pravoslavnega pogleda na zakramente, temveč mu posredno postavlja tudi izzivalna vprašanja za njegov lastni čas in prostor, zlasti v razmerju do miselnosti in prakse $\mathrm{v}$ Katoliški cerkvi in zunaj 
nje, ki med drugim zadevajo (ne)ozaveščeno prejemanje zakramentov, (ne)poznavanje liturgičnega izročila in (ne)izoblikovanost liturgične zavesti. Branje omenjenega dela je tako koristno zato, ker na svež in zavzet način odkriva obzorja preteklosti, sedanjosti in prihodnosti. V tem pogledu bi veljalo razmisliti o nadaljnjem prevajanju Schmemannovih del, vsaj dveh podobno temeljnih monografij: Zgodovinska pot pravoslavja (Istoričeskij put' pravoslavija, 1954) in Evharistija: zakrament kraljestva (The Eucharist: Sacrament of the Kingdom, 1988). 